\title{
Kinetics of Flux Dissolution in Oxygen Steelmaking
}

\author{
Neslihan DOGAN, Geoffrey A. BROOKS and Muhammad Akbar RHAMDHANI \\ Faculty of Engineering and Industrial Science, Swinburne University of Technology, Hawthorn, VIC 3122, Australia. \\ E-mail: ndogan@swin.edu.au
}

(Received on April 2, 2009; accepted on June 16, 2009)

\begin{abstract}
A mathematical model has been developed to predict the dissolution rate of added fluxes such as lime and dolomite as a sub-model of an overall kinetic model of top-blown oxygen steelmaking process. The calculation of dissolution rates included dimensionless analysis technique as well as the evolution of gas generated due to decarburization reaction during the blowing process. The progress of flux dissolution and the amount of slag generated were predicted as a function of saturation concentration of $\mathrm{CaO}$ and $\mathrm{MgO}$ in the slag, CO gas flow rate and the physical properties of slag throughout the blow. The results from the model were consistent with the plant data from the study of Cicutti et al. The influences of variations in solid particle size and flux addition rate on flux dissolution were also investigated. It has been shown in this study that the amount of flux dissolved in oxygen steelmaking process is accelerated if the addition rate of flux is increased or if the size of flux particle is decreased.
\end{abstract}

KEY WORDS: lime; dolomite; dissolution rate; mass transport; stirring intensity; oxygen steelmaking.

\section{Introduction}

In oxygen steelmaking, flux is added in a solid form to the process to form a basic slag that will limit the degradation of the refractory lining and will remove oxidation products such as phosphorus and silicon. The progress of flux dissolution determines the efficiency of fluxing of impurities and prolongs contact time with refractory lining. Since top blowing process takes only $15-20 \mathrm{~min}$ to refine impurities from the steel, full utilization of flux added requires rapid flux dissolution in the slag. Therefore, the degree of flux dissolution is of crucial interest for understanding the progress of slag-metal reactions in the oxygen steelmaking system.

There have been several experimental studies ${ }^{1-15)}$ on the mechanism and kinetics of flux dissolution into stirred and stagnant slag baths at high temperatures. However, these are generally limited studies with experimental conditions, such as the stirring intensity, composition and temperature of molten slag system, which can be practically studied at laboratory scale. Although these studies provide qualitative information on flux dissolution, it is difficult to apply the findings to predict the kinetics of flux dissolution under full-scale operating conditions. There have been also studies ${ }^{16-20)}$ on the dissolution of solid into liquids related to the effects of mixing characteristics of liquids induced by gas bubbles for metallurgical systems at high temperatures. However, the effect of gas generation on flux dissolution has never been reported in literature.

The aim of the present study is to provide better knowledge on the rate of flux dissolution under full-scale operating conditions at high temperatures. In the present study, the effects of composition of slag and stirring intensity in- duced by $\mathrm{CO}$ gas bubbles on the kinetics of flux dissolution were investigated using numerical solution of equations with validation of the model using industrial study by Cicutti and his co-workers. ${ }^{21,22)}$ The following specific issues associated with flux dissolution were also investigated:

(1) the effects of particles size on dissolution

(2) the effects of flux addition rates on dissolution

\section{Theoretical Background}

The dissolution of solid oxides in molten slag systems proceeds depending on the temperature, the composition of slag and mixing conditions between metal and slag. When solid oxide dissolves into the melt, it may form an intermediate product at or near the solid/melt interface. The dissolution can be controlled by chemical reaction, diffusion through the solid intermediate product, diffusion through liquid phase boundary layer or by mixed control. ${ }^{11,23)}$ The formation of intermediate product retards the dissolution however, it does not stop the dissolution. ${ }^{1-3)}$ The dissolution mechanism of solid lime and dolomite in oxygen steelmaking process is described in the following section.

\subsection{Dissolution Mechanism of Lime}

The dissolution mechanism of lime is mainly influenced by the composition of slag and limited by the saturation level of dicalcium silicate in the slag. ${ }^{24)}$ In basic oxygen steelmaking system, the slag can be saturated by lime, dicalcium silicate or tricalcium silicate depending on the ratio of $\mathrm{CaO}$ to $\mathrm{SiO}_{2}$. Saturation with dicalcium silicate mainly occurs at high silica concentration in the slag phase..$^{1,4,6,25)}$

Based on the previous studies, when lime dissolves in silica containing slag, a film of dicalcium silicate, 
$2 \mathrm{CaO} \cdot \mathrm{SiO}_{2}$, is formed at the periphery of lime particles, which prevents direct contact of particles with molten slag and reduces the dissolution of particles; this is suggested to occur for a mole ratio of $\mathrm{CaO} / \mathrm{SiO}_{2}<2$. ${ }^{6,10,25,26)}$ Cracks may occur in the film layer and $\mathrm{FeO}$ in the slag penetrates through the film layer resulting in a $\mathrm{FeO}$ rich layer between dicalcium silicate layer and lime. Matsushima et al. ${ }^{1)}$ investigated the mechanism and rate of solid lime dissolution into stirred $\mathrm{CaO}-\mathrm{SiO}_{2}-\mathrm{FeO}$ and $\mathrm{CaO}-\mathrm{SiO}_{2}-\mathrm{Al}_{2} \mathrm{O}_{3}$ slag systems at temperatures ranging from 1400 to $1600^{\circ} \mathrm{C}$ using a finger test technique. They observed the formation of $2 \mathrm{CaO} \cdot \mathrm{SiO}_{2}$ and $3 \mathrm{CaO} \cdot \mathrm{SiO}_{2}$ on the surface of lime particles. They suggested that the thickness of $2 \mathrm{CaO} \cdot \mathrm{SiO}_{2}$ film depends on the $\mathrm{FeO}$ content of the slag. A thicker film forms when the concentration of $\mathrm{FeO}$ in slag is less than 20 mass $\%$. Above this level, the film formation discontinues and dissolution of lime progresses. ${ }^{1)}$ Hamano et al. $^{2)}$ also investigated the dissolution rate of lime into different $\mathrm{CaO}-\mathrm{SiO}_{2}-\mathrm{FeO}_{x}-\mathrm{P}_{2} \mathrm{O}_{5}$ slag systems at $1300^{\circ} \mathrm{C}$ using the finger test technique. They observed the formation of $\mathrm{CaO}-\mathrm{FeO}$ and $2 \mathrm{CaO} \cdot \mathrm{SiO}_{2}$ layer as a function of immersion time. Several researchers have found that the dissolution of lime is limited by $\mathrm{CaO}$ diffusion through a boundary layer liquid phase. ${ }^{1,6,24)}$

\subsection{Dissolution Mechanism of Dolomite}

$\mathrm{MgO}$ has a tendency to form a solid product with $\mathrm{FeO}$ in steelmaking slags with a low melting point. ${ }^{10)}$ When dolomite dissolves in slag, slag penetrates to the dolomite through the pores of the dolomite particles. $\mathrm{CaO}$ and $\mathrm{MgO}$ diffuse out of the dolomite due to the concentration difference. Accordingly, the solid solution, $(\mathrm{Fe}, \mathrm{Mg}) \mathrm{O}$, layer occurs on the surface of dolomite particles or at a distance from the surface. A film layer of $2 \mathrm{CaO} \cdot \mathrm{SiO}_{2}$ may also occur between the FeO-rich layer and molten slag. ${ }^{3,4,10)}$ Williams et $\mathrm{al}^{4)}{ }^{4}$ investigated the dissolution mechanism and kinetics of lime and dolomitic lime in iron silicate melts under stirred and stagnant conditions at $1300^{\circ} \mathrm{C}$. They suggested that the presence of $\mathrm{MgO}$ (above 5 mass\%) in the slag prevents the formation of continuous dicalcium silicate rather, a porous film layer is formed. This behaviour has a crucial influence on dissolution of lime and fluxing of impurities from liquid metal. ${ }^{10)}$ Additionally, Umakoshi et $a l^{3)}$ measured the dissolution rate of sintered burnt dolomite in a stirred $\mathrm{Fe}_{x} \mathrm{O}-\mathrm{CaO}-\mathrm{SiO}_{2}$ slags containing $\mathrm{FeO}$ from 20 to 65 mass $\%\left(\% \mathrm{CaO} / \% \mathrm{SiO}_{2}=1\right)$ at temperatures of 1350 to $1425^{\circ} \mathrm{C}$. They observed that the $\mathrm{CaO}$ and $\mathrm{MgO}$ in dolomite reacted individually and dicalcium silicate and magnesiowustite solid solution were formed at the periphery of the dolomite particles. They suggested that diffusion of $\mathrm{MgO}$ through a boundary layer is the rate limiting step when the $\mathrm{FeO}$ content of slag phase is above 20 (mass\%) while diffusion of $\mathrm{CaO}$ through boundary layer is rate limiting for small $\mathrm{FeO}$ concentrations (mass\% $\mathrm{FeO}<20$ ). They also observed that $2 \mathrm{CaO} \cdot \mathrm{SiO}_{2}$ film layer disappears under forced convection conditions and the formation of (Fe, $\mathrm{Mg}$ ) O is hardly affected by the intensity of stirring. ${ }^{3)}$

\section{Model Development}

In this model, the dissolution rate of fluxes, $v_{\mathrm{r}}(\mathrm{m} / \mathrm{min})$, into slag system is expressed as a function of the rate of decrease of the thickness of solid flux particles, assuming spherical geometry

$$
v_{\mathrm{r}}=-\frac{1}{S} \frac{d V}{d t}=-\frac{d r}{d t}
$$

where $v_{\mathrm{r}}$ is the rate of decrease of the radius of solid particle $(\mathrm{m} / \mathrm{min}), V$ is the volume of particle $\left(\mathrm{m}^{3}\right), S$ is surface area of particle $\left(\mathrm{m}^{2}\right), r$ is the radius of particle $(\mathrm{m})$ and $t$ is time (min).

The number of particles dissolved in the emulsion is proportional to the particle concentration in the emulsion. Calculations for different individual particle size were carried out separately and the results were then added. The amount of lime, $W_{\mathrm{L}}$ and dolomite, $W_{\mathrm{D}}$ dissolved in the emulsion phase as a function of time was determined using

$$
\begin{aligned}
& \frac{d W_{\mathrm{L}}}{d t}=\rho_{\mathrm{L}} S \frac{d r}{d t} n_{\mathrm{L}} \\
& \frac{d W_{\mathrm{D}}}{d t}=\rho_{\mathrm{D}} S \frac{d r}{d t} n_{\mathrm{D}}
\end{aligned}
$$

where $\rho_{\mathrm{L}}$ is density of lime $\left(\mathrm{kg} / \mathrm{m}^{3}\right)$ and $\rho_{\mathrm{d}}$ is density of dolomite $\left(\mathrm{kg} / \mathrm{m}^{3}\right) . n_{\mathrm{L}}$ and $n_{\mathrm{D}}$ are the number of lime and dolomite particles, respectively. The total amount of lime dissolved in emulsion at time $t, M_{\mathrm{d}, \mathrm{L}}^{t}$ is determined by summation of total amount of lime dissolved at time $t-\Delta t$ and amount of lime dissolved at given time step, $\Delta t$ (see Eq. (4)). The same calculation procedure is applied for the total amount of dolomite dissolved at time $t-\Delta t$ using Eq. (5).

$$
\begin{aligned}
M_{\mathrm{d}, \text { Lime }}^{t} & =M_{\mathrm{d}, \text { Lime }}^{t-\Delta t}+\frac{d W_{\mathrm{L}}}{d t} \Delta t \\
M_{\mathrm{d}, \text { Dolomite }}^{t} & =M_{\mathrm{d}, \text { Dolomite }}^{t-\Delta t}+\frac{d W_{\mathrm{D}}}{d t} \Delta t
\end{aligned}
$$

where the subscript d refers to dissolved flux in emulsion. In this study, the amount of slag formed for each time step was determined using predetermined $\mathrm{CaO}$ content (in mass \%) in the emulsion phase given by Eq. (6).

$$
M_{\text {slag }}^{t}=\frac{100 M_{\mathrm{d}, \mathrm{CaO}}^{t}}{\operatorname{mass} \% \mathrm{CaO}}
$$

\subsection{Rate-determining Mechanism of Lime Dissolution}

In this study, the rate of dissolution is assumed to be controlled by $\mathrm{CaO}$ diffusion through a boundary layer. ${ }^{25}$ The dissolution rate can be calculated by the model suggested by Matsushima et al. ${ }^{1)}$

$$
-\frac{d r}{d t}=k \frac{\rho_{\mathrm{s}}}{100 \rho_{\mathrm{L}}} \Delta(\% \mathrm{CaO})
$$

where $\rho_{\mathrm{s}}$ is the density of slag $\left(\mathrm{kg} / \mathrm{m}^{3}\right)$ and $k$ is the mass transfer coefficient of $\mathrm{CaO}$ in the slag $(\mathrm{m} / \mathrm{min}) . \Delta(\% \mathrm{CaO})$ is the difference between the concentration of $\mathrm{CaO}$ in the slag phase and its solubility in the slag phase (in mass\%). In this 
model, the solubility of $\mathrm{CaO}$ was obtained from ternary phase diagram of $\mathrm{FeO}-\mathrm{SiO}_{2}-\mathrm{CaO}$ considering intersections between the liquidus line with a straight line connecting the point $2 \mathrm{CaO} \cdot \mathrm{SiO}_{2}$. In this method, the maximum $\mathrm{CaO} / \mathrm{SiO}_{2}$ should be the value on the liquidus line of $2 \mathrm{CaO} \cdot \mathrm{SiO}_{2}$ saturated region. ${ }^{27)}$ Details of the calculation procedure for dissolution mechanism and rate equation of lime are given in Fig. 1.

\subsection{Rate-determining Mechanism of Dolomite Disso- lution}

In this model, the dissolution of dolomite depends on the $\mathrm{FeO}$ content of slag phase. The dissolution rate of dolomite is controlled by dissolution of $\mathrm{CaO}$ through a liquid boundary layer for slags containing $\mathrm{FeO}$ less than 20 mass\%. ${ }^{3}$ ) The relationship is expressed as follows ${ }^{3)}$;

$$
-\frac{d r}{d t}=\left(1+\frac{M_{\mathrm{MgO}}}{M_{\mathrm{CaO}}}\right) k \frac{\rho_{\mathrm{s}}}{100 \rho_{\mathrm{d}}} \Delta(\% \mathrm{CaO})
$$

On the contrary, if $\mathrm{FeO}$ content of slag is above 20 mass $\%$, the change in the radius of dolomite particle was calculated using the following correlation ${ }^{3)}$;

$$
-\frac{d r}{d t}=\left(1+\frac{M_{\mathrm{CaO}}}{M_{\mathrm{MgO}}}\right) k \frac{\rho_{\mathrm{s}}}{100 \rho_{\mathrm{d}}} \Delta(\% \mathrm{MgO})
$$

where $\Delta(\% \mathrm{MgO})$ is the difference between the concentration of $\mathrm{MgO}$ in the slag phase and its saturation in the slag phase (in mass\%). In this model, the solubility of $\mathrm{MgO}$ was determined using modified relationship for $\mathrm{CaO}-\mathrm{MgO}-$ $\mathrm{FeO}-\mathrm{SiO}_{2}$ slag saturated with magnesiowustite at $1600^{\circ} \mathrm{C}$ reported in literature. ${ }^{27)}$ This relationship is modified by Chen et al. ${ }^{28)}$ They suggested a relationship between $\mathrm{MgO}$ concentration for a given slag composition at $1600^{\circ} \mathrm{C}$ and slag temperature to predict the solubility of $\mathrm{MgO}$ at various temperatures. This relationship was applied in this study to calculate the saturation concentration of $\mathrm{MgO}$. It should be noted that the dissolution of refractory lining to the system was not considered in this model. Therefore, the model tends to under estimate the total volume of slag. The calculation procedure for dissolution mechanism and rate equations of dolomite and lime are given in Fig. 1.

\subsection{Mass Transfer Coefficient}

Previous experimental studies ${ }^{1-4)}$ provide qualitative information for estimating mass transfer coefficients. However, these values are not applicable in this model due to different parameters and operating conditions such as shape of solid particles, slag temperature and stirring intensity. Semi-empirical relationships based on Sherwood, Reynolds and Schmidt numbers have been widely used to estimate the mass transfer coefficient of different shaped solids in steelmaking systems under different flow conditions. ${ }^{1-4,14,15)}$ The correlation proposed by Ranz and Marshall ${ }^{29)}$ is;

$$
\mathrm{Sh}=2+0.6 \mathrm{Re}^{1 / 2} \mathrm{Sc}^{1 / 3}
$$

This correlation has been widely applied in the literature. However, this correlation is valid for low Reynolds number $(2<\mathrm{Re}<200)$. Clift et al. $^{30)}$ proposed a correlation for rigid spheres, which can be applied for high Schmidt number $(\mathrm{Sc}>200)$ and $100<\operatorname{Re}<2000$. The relationship is ${ }^{30)}$

$$
\mathrm{Sh}=1+0.724 \mathrm{Re}^{0.48} \mathrm{Sc}^{1 / 3}
$$

In this model, Reynolds number is related to the particle size and settling velocity of the particles. The Schmidt number for $\mathrm{CaO}$ and $\mathrm{MgO}$ can be found as a function of physical properties of slag and diffusivities of lime and

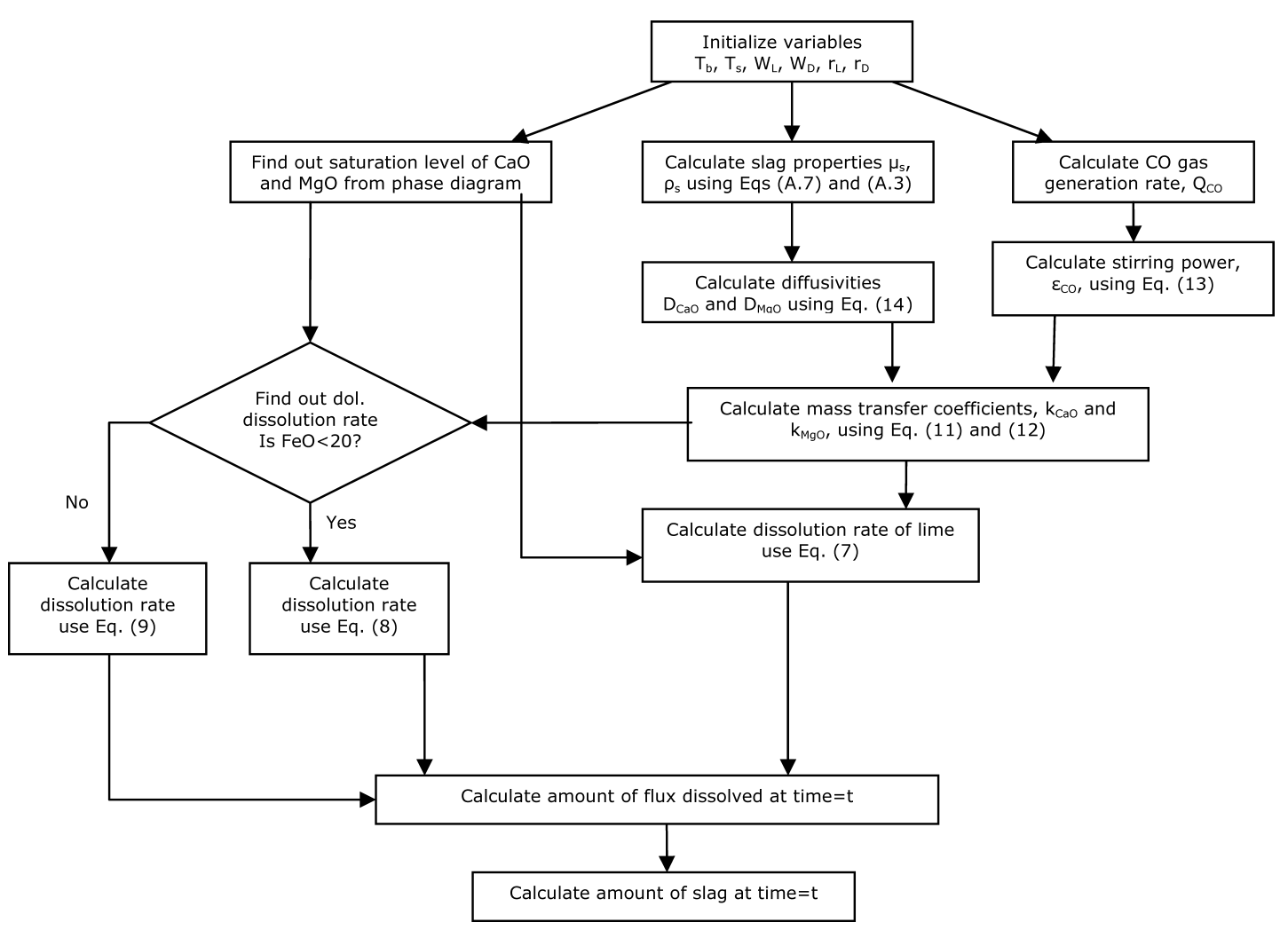

Fig. 1. Preliminary algorithm of flux dissolution program. 
dolomite lumps. Physicochemical properties of slag were calculated from literature ${ }^{31,32)}$ which is described in the Appendix.

In oxygen steelmaking process, turbulent flow occurs in the vicinity of oxygen lance due to the rising of $\mathrm{CO}$ gas bubbles during the blow, generated from the decarburization. This rising bubbles generates a circulation flow that accelerates the mass transfer rate of solid particles in the slag. Accordingly, Sherwood number can be related to stirring intensity induced by $\mathrm{CO}$ gas bubbles using ${ }^{33)}$;

$$
\mathrm{Sh}=2+0.4\left[\frac{\varepsilon_{\mathrm{CO}} d_{\mathrm{p}}^{4}}{v_{\mathrm{s}}^{3}}\right]^{1 / 4} \mathrm{Sc}^{1 / 3}
$$

where $\varepsilon_{\mathrm{CO}}$ is stirring power $(\mathrm{W} / \mathrm{kg}), d_{\mathrm{p}}$ is diameter of particle $(\mathrm{m})$ and $v_{\mathrm{s}}$ is kinematic viscosity of slag $\left(\mathrm{m}^{2} / \mathrm{min}\right)$. Accordingly, Eq. (12) directly relates mass transfer of particles with the stirring intensity (rather than particle velocity) influencing the mixing phenomena in slag-gas-metal emulsion. $^{25)}$ The stirring power, $\varepsilon_{\mathrm{CO}}$, can be determined as a function of $\mathrm{CO}$ gas flow rate generated by decarburization reaction using ${ }^{34)}$

$$
\varepsilon_{\mathrm{CO}}=14.2 \frac{Q_{\mathrm{CO}} T_{\mathrm{s}}}{M_{\mathrm{s}}} \log \left(1+\frac{h P_{\mathrm{a}}}{1.46}\right)
$$

where $Q_{\mathrm{CO}}$ is gas volume flow rate $\left(\mathrm{Nm}^{3} / \mathrm{min}\right)$ generated by decarburization reaction, $T_{\mathrm{s}}$ is temperature of slag $(\mathrm{K}), M_{\mathrm{s}}$ is weight of slag $(\mathrm{kg}), h$ is height of slag $(\mathrm{m}), P_{\mathrm{a}}$ is the ambient pressure of the system $(\mathrm{Pa})$. The applications of mass transfer coefficient and stirring power in this model are illustrated in Fig. 1.

\subsection{Diffusivity}

There is a limited knowledge on the diffusivities of $\mathrm{MgO}$ and $\mathrm{CaO}$ in oxygen steelmaking slags. Umakoshi et al. ${ }^{3)}$ applied dimensionless mass transfer correlation and estimated the diffusivity of $\mathrm{MgO}$ as $1.5 \times 10^{-5}$ to $1.8 \times 10^{-5} \mathrm{~cm}^{2} / \mathrm{s}$ for $\mathrm{FeO}-\mathrm{CaO}-\mathrm{SiO}_{2}$ slags $\left(\mathrm{CaO} / \mathrm{SiO}_{2}=1\right.$ and $\mathrm{FeO}=20$ to 70 mass\%). In the case of lime dissolution, Matsushima et $a l .{ }^{1)}$ used the diffusivity of $\mathrm{CaO}$ for $20 \% \mathrm{FeO}-40 \% \mathrm{CaO}-$ $40 \% \mathrm{SiO}_{2}$ slags of a value of $2.7 \times 10^{-5}\left(\mathrm{~cm}^{2} / \mathrm{s}\right)$. To the authors knowledge, these data are the only available data in literature providing information on diffusivities of $\mathrm{CaO}$ and $\mathrm{MgO}$ for basic oxygen steelmaking slags using the rotating cylinder technique at $1400^{\circ} \mathrm{C}$. In this study, the values for diffusivities of $\mathrm{CaO}$ and $\mathrm{MgO}$ are chosen to be $2.7 \times 10^{-5}$ and $1.6 \times 10^{-5} \mathrm{~cm}^{2} / \mathrm{s}$, respectively at $1400^{\circ} \mathrm{C}$. The relationship between diffusivity in liquids and temperature and viscosity of liquid by the Stokes-Einstein and Eyring equations is used to calculate the diffusivities of $\mathrm{CaO}$ and $\mathrm{MgO}$ for various temperatures.

$$
D \propto \frac{T_{\mathrm{s}}}{\mu_{\mathrm{s}}}
$$

Turbulent diffusivity is introduced for turbulent flow conditions and is assumed to be twice of the molecular diffusivity. ${ }^{25)}$ Diffusivities of $\mathrm{CaO}$ and $\mathrm{MgO}$ were then determined as a function of temperature and viscosity of slag. These diffusivity values are used to calculate the dissolution rate of lime and dolomite in Eqs. (7), (8) and (9) as given in Fig. 1.

\subsection{Formulation of the Model}

In this model, a time step of 1 min was selected to be consistent with the input data available in literature ${ }^{21,22)}$ to calculate the amount of $\mathrm{CaO}$ and $\mathrm{MgO}$ dissolved at the end of each time step. The sequence of calculation procedure is shown in Fig. 1.

\subsection{Input Data}

The dissolution rate of lime and dolomite is predicted as a function of stirring intensity, physicochemical properties of slag, composition of slag, temperature profile of the system and saturation limits of $\mathrm{CaO}$ and $\mathrm{MgO}$ using the industrial data from the study of Cicutti and his co-workers. ${ }^{21,22)}$

Table 1 shows the operating conditions of oxygen steelmaking process taken from the study of Cicutti et al. ${ }^{22)}$ Oxygen is introduced to the process through the lance. Bottom stirring is also applied to enhance the mass transfer rates, particularly towards the end of the blow. One-thousand killograms of lime and $1700 \mathrm{~kg}$ dolomite were added before starting the blow. The remaining amount of lime was continuously added during the first $7 \mathrm{~min}$ of the blow with a constant addition rate whereas the remaining amount of dolomite was added at 7 th minute after the blow started. It is also assumed that $1200 \mathrm{~kg}$ lime and $1000 \mathrm{~kg}$ dolomite

Table 1. Data used for calculations. ${ }^{22)}$

\begin{tabular}{ll}
\hline Amount of hot metal charged & $170000 \mathrm{~kg}$ \\
Amount of scrap charged & $30000 \mathrm{~kg}$ \\
Amount of iron ore charged & $1900 \mathrm{~kg}$ \\
& $1000 \mathrm{~kg}$ before starting the blow \\
Amount of lime charged & $6600 \mathrm{~kg}$ in the first half of the blow \\
& $1700 \mathrm{~kg}$ before starting the blow \\
Amount of dolomite charged & $1100 \mathrm{~kg}$ in the first half of the blow \\
Initial diameter of lime particle & $0.03 \mathrm{~m}$ \\
Initial diameter of dolomite particle & $0.045 \mathrm{~m}$ \\
Initial hot metal temperature & $1350^{\circ} \mathrm{C}$ \\
Oxygen blow & $620 \mathrm{~m}^{3} / \mathrm{min}^{2} 6$ hole lance \\
Inert gas $\left(\right.$ Ar $\left./ \mathrm{N}_{2}\right)$ & $2.5-8.33 \mathrm{~m} / \mathrm{min}$ through the bottom \\
Lance height & $2.5 \mathrm{~m} / 2.2 \mathrm{~m} / 1.8 \mathrm{~m}$ \\
\hline
\end{tabular}




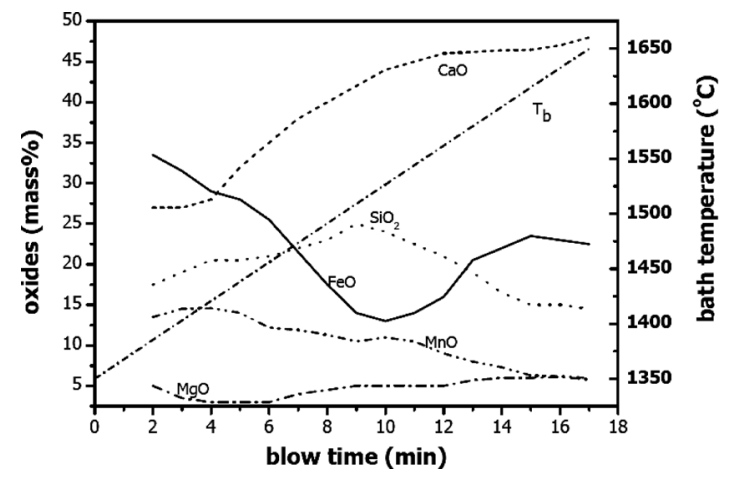

Fig. 2. Evolution of slag composition and temperature profile of bath with time. ${ }^{22)}$

dissolved in the slag at the end of first minute to be consistent with the industrial data.

Figure 2 shows the evolution of slag composition measured during the blow from the study by Cicutti et al. ${ }^{22)}$ Initially, $\mathrm{FeO}$ content in slag increases rapidly. During the main blow, FeO level is reduced significantly by carbon in metal due to the high decarburization rate. Towards the end of the blow, FeO content in slag builds up again as the decarburization rate decreases. The temperature profile of the bath is also illustrated in Fig. 2. In this study it is assumed that it increases linearly from 1350 to $1650^{\circ} \mathrm{C}$ for the given industrial practice. The calculation procedure for temperature of bath and slag are given in Appendix A.

\section{Results and Discussion}

\subsection{CO Evolution}

$\mathrm{CO}$ gas generated provides a circulation flow in the system. However, some amounts of $\mathrm{CO}$ gas generated escape from the emulsion and leave the system. Therefore, the actual amount of $\mathrm{CO}$ gas influencing the stirring power should be investigated.

Thus, the cumulative $\mathrm{CO}$ gas produced enhances void fraction of gas in the emulsion phase. For high rates of decarburization, particularly during the main blow, $\mathrm{CO}$ gas generation rate increases and not all $\mathrm{CO}$ gas generated can escape from the emulsion. The excessive amount of $\mathrm{CO}$ gas in the emulsion may cause a slopping problem because the critical height of foamy slag reached when the bubble plume completely fills the system. ${ }^{25)}$ Therefore, it is important to predict the height of foamy slag for a better process control of the system. Accordingly, the critical height of foamy slag is investigated as a function of different volume fraction of $\mathrm{CO}$ gas in the emulsion in this model.

There are several ways of calculating the height of foamy slag as a function of physical properties of slag and $\mathrm{CO}$ gas generation rate reported in literature. ${ }^{35-39)}$ However, all these equations give different values for height of the foamy slag for process conditions. For simplicity, in this study the height of foam is approximated by ${ }^{39)}$;

$$
h_{\mathrm{f}}=\frac{M_{\mathrm{s}}}{\rho_{\mathrm{s}} A\left(1-\varphi_{\mathrm{g}}\right)}
$$

where $h_{\mathrm{f}}$ is the height of foamy slag $(\mathrm{m}), A$ is slag area $\left(\mathrm{m}^{2}\right)$, and $\varphi_{\mathrm{g}}$ is gas fraction in emulsion.

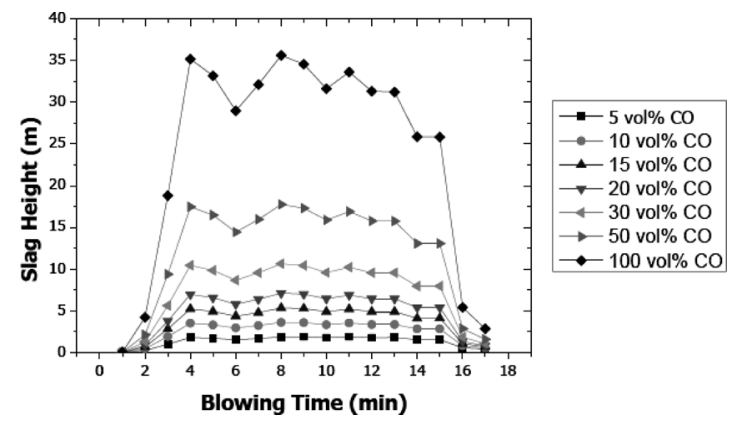

Fig. 3. Comparison of slag height as a function of volume of gas available in the emulsion during the blow.

The predicted foam height of oxygen steelmaking process as a function of volume fraction of $\mathrm{CO}$ gas hold up in the emulsion during the blow is given in Fig. 3. In the calculation, $\mathrm{CO}$ gas generation rate is obtained from the evolution of carbon content in the metal bath as a function of time and we assumed that all the carbon is converted to $\mathrm{CO}$ gas. The volume fraction of $\mathrm{CO}$ gas is varied between 5 and $100 \%$. If we assume more than $10 \mathrm{vol} \%$ of $\mathrm{CO}$ gas is held up in the emulsion, the predicted height of the slag exceeds that might cause slopping. (i.e. $>5 \mathrm{~m}$ ) The values of foamy height calculated on the basis of $10 \mathrm{vol} \% \mathrm{CO}$ gas assumption lie at the edge of slopping. This finding implies that only a small proportion of the $\mathrm{CO}$ gas generated is held up in the emulsion. In this study, we assume that $90 \%$ of $\mathrm{CO}$ gas generated at any time bypasses the emulsion region (i.e. leaves close to the lance) and the $10 \%$ of CO gas contributes to foaming and stirring the emulsion. Subsequently, all calculations reported have been carried out based on the assumption of $10 \mathrm{vol} \%$ of $\mathrm{CO}$ gas generated being held up in the emulsion. However, this assumption will be further discussed.

\subsection{Determination of Mass Transfer Coefficient}

The earlier study ${ }^{1)}$ was carried out at laboratory scale with a defined geometry, where the velocity profile is known. This is not the case in an oxygen steelmaking vessel, where the velocity fields are complex, not homogenous and not known (e.g. some parts of the slag are comparatively stagnant). In this study, two approaches are compared: (a) assuming the velocity is simply the settling velocity and (b) using a correlation for turbulent flow induced by gas bubbling. This methodology is outlined in Fig. 1 and described in the earlier section "Mass Transfer Coefficient". Accordingly, different correlations have been used to determine the appropriate mass transfer correlation for the calculation of dissolution rate of lime and dolomite particles in the slag. The mass transfer coefficient of sphere particles under laminar and turbulent flow conditions was determined using Eqs. (13) and (14), respectively. The results for the weight of undissolved lime were compared with those reported by Cicutti et al. given in Fig. 4.

The measured values for the industrial practice lie between those values from two different assumptions. A laminar flow assumption underpredicts the dissolution rate but even using only $10 \%$ CO gas generated to stir the emulsion overpredicts the dissolution. Therefore, the authors suggest that there are two different flow regimes in the slag due to 


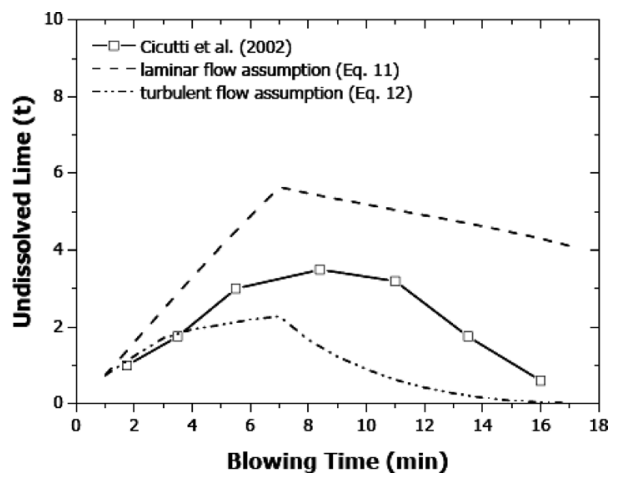

Fig. 4. Comparison of the weight of undissolved lime as a function of time between predicted values by assuming laminar and turbulent flow and those reported by Cicutti et $a .^{21)}$

the stirring conditions. The regime near the lance has a higher stirring intensity due to the $\mathrm{CO}$ gas generation. This regime can be termed "turbulent". The regime far away from the lance and close to the refractory lining is expected to be more stagnant regime. Therefore, dissolution of solid particles in this stagnant regime takes place at a slower rate compared to that in the turbulent regime.

The flow regime in the vessel is defined due to the Reynolds number as a function of settling velocity of solid particles. In the early part of the blow, the values for Reynolds number lies in the transient regime $(100<\mathrm{Re}<$ 500). However, as the size of particles becomes smaller, the movement of particles is faster and the flow becomes turbulent. As a result, it is not possible to model the flux dissolution using one simple correlation for understanding the complex nature of oxygen steelmaking process. As a practical solution to the problem, we introduced a constant $(\beta)$ to modify the settling velocity of the particles to provide a means of modelling the data. The correlation by Clift et $a l .{ }^{30)}$ is modified using following relationship;

$$
\begin{gathered}
\mathrm{Sh}=1+0.724\left(\operatorname{Re}^{\prime}\right)^{0.48} \mathrm{Sc}^{1 / 3} \\
\operatorname{Re}^{\prime}=\beta \operatorname{Re}=\beta \frac{u_{\mathrm{p}} d_{\mathrm{p}} \rho_{\mathrm{s}}}{\mu_{\mathrm{s}}} .
\end{gathered}
$$

where $u_{\mathrm{p}}$ is settling velocity of particles and $d_{\mathrm{p}}$ is diameter of solid particle. Accordingly, the weight of undissolved lime as a function of $\beta$ were calculated and compared with those reported by Cicutti et al. given in Fig. 5. The predicted amount of undissolved lime for $\beta=10$ is to closer to the measured value of undissolved lime in the slag from the study of Cicutti et al. ${ }^{21)}$ This implies that the stirring effect of $\mathrm{CO}$ gas on the dissolution rate is crucial and should be related to determine the mass transfer coefficient. It may also be necessary to model the emulsion region as multizoned reactor to reflect the stirring near the lance as compared to the wall region. CFD model may also be useful in studying the variation in flow conditions around flux particles as a function of changing process conditions. The recommended value of $\beta$ is 10 for the practical applications to predict the overall dissolution rate of lime and dolomite for oxygen steelmaking process. The algorithm to model the dissolution of flux in the emulsion for $\beta=10$ is illustrated in Fig. 6.

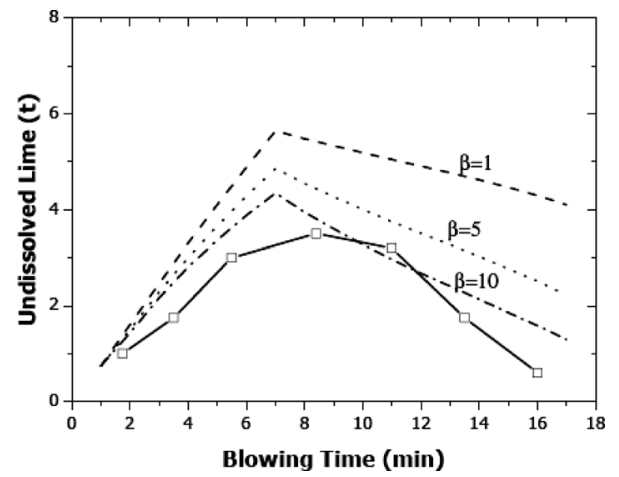

Fig. 5. Comparison of the weight of undissolved lime as a function of different $\beta$ values with those reported by Cicutti et $a .^{21)}$

The authors would prefer not to have to introduce this factor but the introduction of $\beta$ is both practical (i.e. we have produced a model that will be useful to steelmakers) and the authors have openly described the limitation of this approach. We hope this paper will stimulate further research on the stirring patterns within the emulsion that will in future allow a more comprehensive treatment of this problem. We should say, that this limitation aside, we believe this study is the most scientifically rigorous treatment of flux dissolution available in the literature.

\subsection{Evolution of Amount of Slag}

The flux dissolution model using Eq. (16) for $\beta=10$ is validated using the study of Cicutti et al. ${ }^{21)}$ Figure 7 shows the results of the slag weight changes during the blow compared with those reported by Cicutti et al. ${ }^{21)}$ Both the measured silicon content in the metal and slag phase during the practice and flux additions to the process have been used to estimate the slag weight. The results of these calculations for slag weight are illustrated as Sample 1 and Sample 2 in Fig. 7. Initially (between 2-4 min), slag weight increases linearly and remains constant during the time between 5-12 min. Towards the end of the blow, it increases linearly. The maximum and minimum values of slag weight with time as estimated by Cicutti et al. are shown in Fig. 7. The results for predicted slag weight from flux dissolution model for $\beta=10$ are consistent with data from the study of Cicutti et al. However, during the main blow (5-12 min), values for weight of the slag are relatively higher than previous results.

\subsection{Effect of Particle Size on Dissolution}

The effect of size of solid lime and dolomite particles on the dissolution of lime and dolomite was investigated using mass transfer correlation given in Eq. (16) for $\beta=10$. Three different sizes for lime $(0.06 \mathrm{~m}, 0.04 \mathrm{~m}$ and $0.02 \mathrm{~m})$ and dolomite particles $(0.09 \mathrm{~m}, 0.06 \mathrm{~m}$ and $0.03 \mathrm{~m})$ were selected in this model. Figures 8 and $\mathbf{9}$ show the predictions for the amount of lime and dolomite dissolved in the slag as a function of various particle sizes. Decreasing the size of lime particles from 0.06 to $0.04 \mathrm{~m}$ increases the dissolution of lime from 4300 to $5460 \mathrm{~kg}$. Solid lime is present in the slag at the end of the blow regardless the particle diameter. In the case of dolomite, particles with a diameter of $0.03 \mathrm{~m}$ dissolved completely at the end of the blow. Solid dolomite 


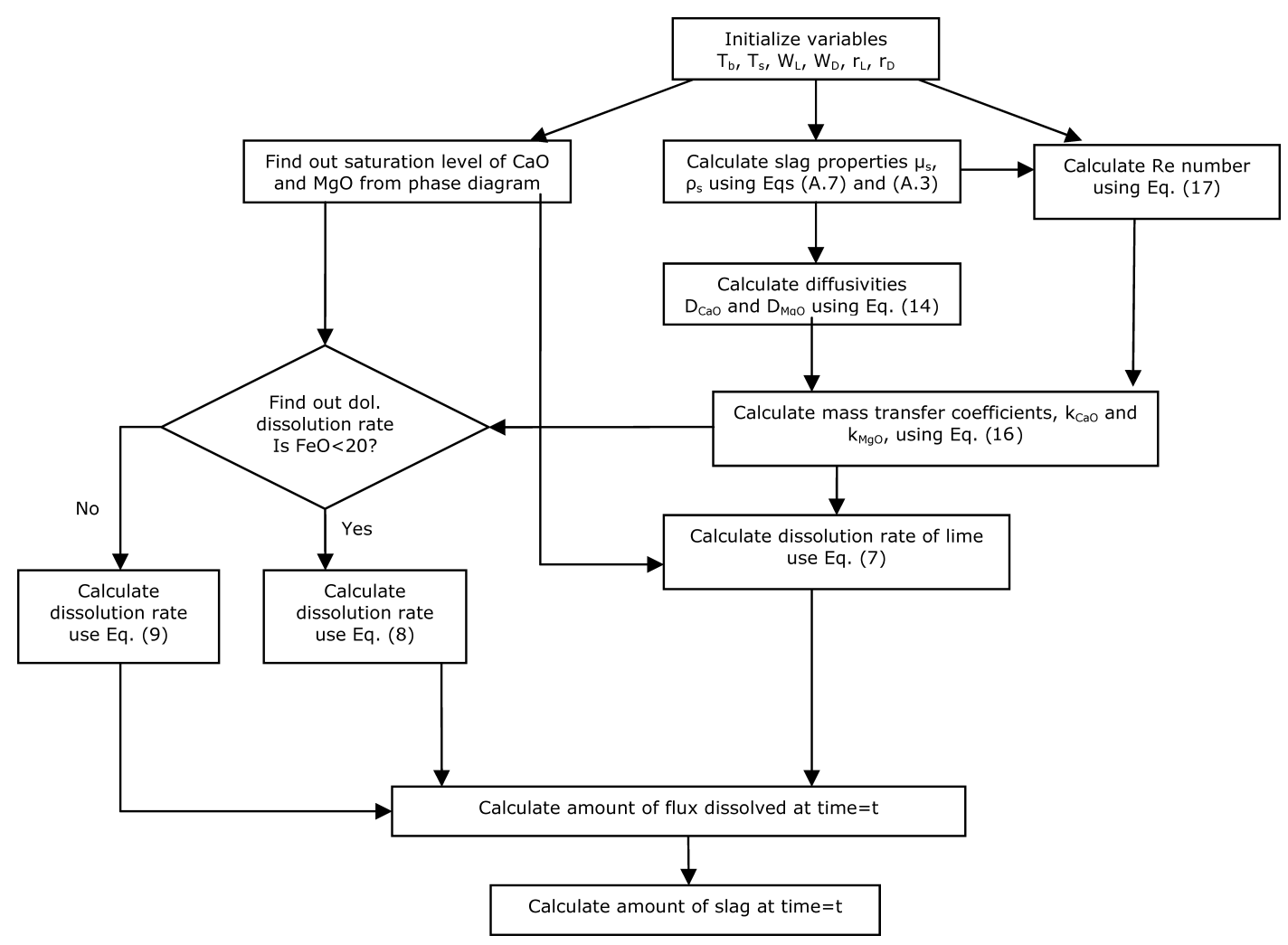

Fig. 6. Algorithm of flux dissolution program.

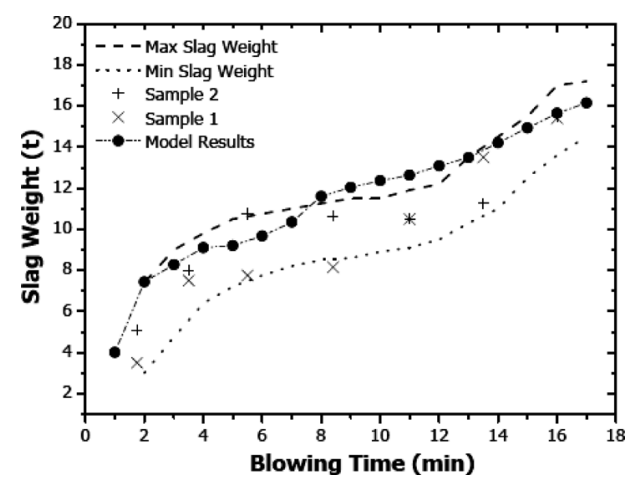

Fig. 7. Comparison of model results for the weight of slag with those reported by Cicutti et $_{\text {al. }}{ }^{21)}$ during the blow.

remained at the end of the blow when the size of particles are $0.06 \mathrm{~m}$ and $0.09 \mathrm{~m}$. As a result, as the size of solid particles is decreased, the amount of flux dissolved increases simultaneously.

\subsection{Effect of Addition Rate of Flux on Dissolution}

The effect of flux addition rate on the kinetics of flux dissolution was investigated. The dissolution rate of lime and dolomite were also calculated using mass transfer correlation given in Eq. (16) for $\beta=10$. Different addition rates for lime and dolomite is given in Table 2. In Case 1 and 3, it is assumed that $1000 \mathrm{~kg}$ of lime and $1700 \mathrm{~kg}$ dolomite were added before starting the blow. The remaining amount of lime and dolomite was continuously added during the first 3 min of the blow with a constant addition rate in Case 1. In Case 2, both the amount of dolomite and lime charge has been increased to $2000 \mathrm{~kg}$ prior to the blow. The remaining amount of lime and dolomite was continuously added dur-

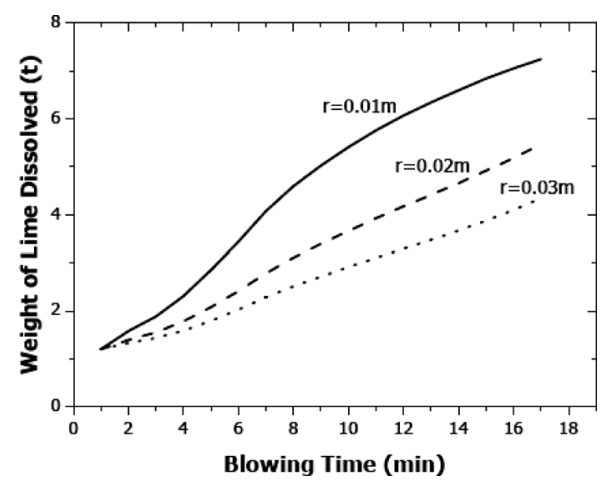

Fig. 8. The weight of lime is predicted as a function of initial size of lime particles during the blow.

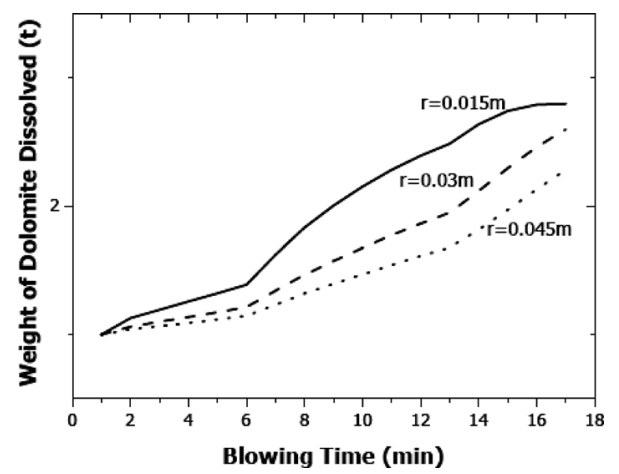

Fig. 9. The weight of dolomite is predicted as a function of initial size of dolomite particles during the blow.

ing the first $7 \mathrm{~min}$ of the blow with a constant addition rate for Case 2 and 3. The results for the weight of lime and dolomite dissolved in the process are given in Figs. 10 and 
Table 2. Different flux additions for top blowing oxygen steelmaking.

\begin{tabular}{|l|l|l|c|}
\cline { 2 - 4 } \multicolumn{1}{c|}{} & \multicolumn{1}{c|}{ lime addition } & \multicolumn{1}{c|}{ dolomite addition } & stages \\
\hline Case 1 & $\begin{array}{l}1000 \mathrm{~kg} \text { prior to blow } \\
6600 \mathrm{~kg} \text { in the early blow }\end{array}$ & $\begin{array}{l}1700 \mathrm{~kg} \text { prior to blow } \\
1100 \mathrm{~kg} \text { in the early blow }\end{array}$ & 3 \\
\hline Case 2 & $\begin{array}{l}2000 \mathrm{~kg} \text { prior to blow } \\
5600 \mathrm{~kg} \text { in the early blow }\end{array}$ & $\begin{array}{l}2000 \mathrm{~kg} \text { prior to blow } \\
800 \mathrm{~kg} \text { in the early blow }\end{array}$ & 7 \\
\hline Case 3 & $\begin{array}{l}1000 \mathrm{~kg} \text { prior to blow } \\
6600 \mathrm{~kg} \text { in the early blow }\end{array}$ & $\begin{array}{l}1700 \mathrm{~kg} \text { prior to blow } \\
1100 \mathrm{~kg} \text { in the early blow }\end{array}$ & 7 \\
\hline
\end{tabular}

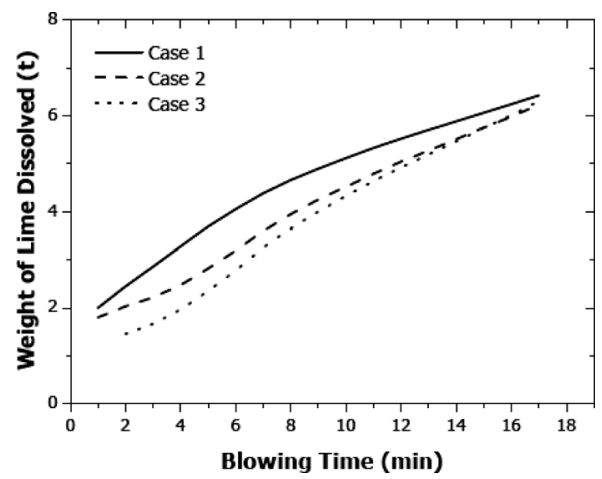

Fig. 10. Predictions for lime dissolution as a function of various addition rates of lime.

\section{1, respectively.}

In lime and dolomite dissolution, an increase in lime and dolomite addition prior to the blow increases the amount of lime and dolomite dissolved in the slag. When flux particles are added continuously in $3 \mathrm{~min}$, higher dissolution of lime would be achieved with compared to constant addition in $7 \mathrm{~min}$. It might be due to the higher concentration difference of $\mathrm{CaO}$ and $\mathrm{MgO}$ that accelerates the dissolution of $\mathrm{CaO}$ and $\mathrm{MgO}$ during the process. As a result, the faster the flux addition is, more flux is dissolved in the system.

These findings are important for oxygen steelmaking process because it provides crucial information on the progress of flux dissolution that affects the refining reactions and also the physical properties of slag. Accordingly, this model can be used for better process control for top blowing oxygen steelmaking process.

\section{Conclusion}

Models for lime and dolomite dissolution as a function of temperature, slag composition and stirring intensity have been developed for oxygen steelmaking slags at high temperatures. The models provide better understanding of crucial factors affecting to the dissolution of fluxes and allows quantitative predictions on flux dissolution. The following conclusions can be drawn from the present study:

(1) Oxygen steelmaking process has heterogenous mixing characteristics. In the beginning, solid particles exist in transient regime with regard to their particle sizes and velocities. As the particle size decreases, particles become faster that stay in turbulent regime. Therefore, it is difficult to predict dissolution rate of solid flux particles using one simple equation. To incorporate the stirring effect with laminar flow conditions, the modified correlation has been proposed for practical reasons. The recommended value for $\beta$ is 10 .

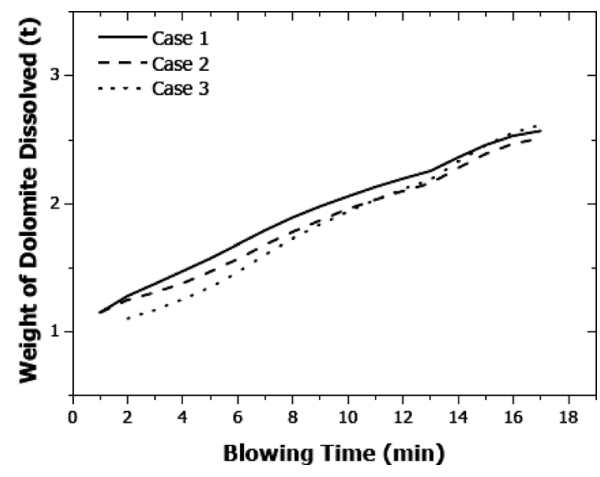

Fig. 11. Predictions for dolomite dissolution as a function of various addition rates of dolomite.

(2) The flow rate of stirring gas has a crucial impact on the rate of dissolution of flux additions. The increase in gas flow rate gives a higher mass transfer rate.

(3) Decreasing particle size of lime and dolomite can effectively promote the dissolution of lime and dolomite particles in oxygen steelmaking slags.

(4) Increasing the addition rate of lime and dolomite both prior to and during the blow increases the amount of flux dissolved in the slag. If the lime addition occurs in three stages rather than seven stages, the higher amount of lime would dissolve in the early part of the blow that would affect the characteristics of slag such as viscosity and fluidity and also would reduce slag attack on refractory lining.

\section{Acknowledgement}

The authors would like to thank Dr. Carlos Cicutti from Centre for Industrial Research at Tenaris, Argentina for his valuable discussions and contributions on the operational data.

\section{REFERENCES}

1) M. Matsushima, S. Yadoomaru, K. Mori and Y. Kawai: Trans. Iron Steel Inst. Jpn., 17 (1977), 442.

2) T. Hamano, M. Horibe and K. Ito: ISIJ Int., 44 (2004), 263

3) M. Umakoshi, K. Mori and Y. Kawai: Trans. Iron Steel Inst. Jpn., 24 (1984), 532.

4) P. Williams, M. Sunderland and G. Briggs: Ironmaking Steelmaking, 9 (1982), 150

5) S. Amini, O. Ostrovski and M. Brungs: 7th Int. Con. on Molten Slags, Fluxes, Salts, The South African Inst. of Mining Metall., Cape Town, South Africa, (2004), 595.

6) T. Hamano, S. Fukagai and F. Tsukihashi: ISIJ Int., 46 (2006), 490.

7) J. W. Evans and C. A. Natalie: 3rd Int. Iron Steel Cong., (1978), 365.

8) A. Chatterjee, B. S. Bhatia and A. K. Das: Trans. Ind. Inst. Met., 36 (1983), 127.

9) G. J. W. Kor, L. J. Martonik and R. A. Miller: 5th Int. Iron Steel Cong., Iron Steel Inst., AIME, Warrandale, PA, USA, (1986), 679.

10) Y. Satyoko and W. E. Lee: Br. Ceram. Trans., 98 (1999), 261. 
11) J. Liu, M. Guo, P. Jones, F. Verhaeghe, B. Blanpain and P. Wollants: J. Eur. Ceram. Soc., 27 (2007), 1961.

12) C. A. Natalie: PhD Thesis, University of California, Berkeley, (1978).

13) J. Yang, M. Kuwabara, T. Asano, A. Chuma and J. Du: ISIJ Int., 47 (2007), 1401

14) S. Amini, M. Brungs, S. Jahanshahi and O. Ostrovski: ISIJ Int., 46 (2006), 1554

15) S. Amini, M. Brungs, S. Jahanshahi and O. Ostrovski: Metall. Mater. Trans. B, 37 (2006), 773

16) A. Sato, R. Nakagawa, S. Yoshimatsu, A. Fuzukuzawa and T. Ozaki: Trans. Iron Steel Inst. Jpn., 21 (1981), 879.

17) K. Mori and T. Sakuraya: Trans. Iron Steel Inst. Jpn., 22 (1982), 984.

18) G. W. Lloyd, D. R. Young and L. A. Baker: Ironmaking Steelmaking, 2 (1975), 49.

19) A. K. Jouhari, R. K. Galgali, P. Chattopadhyay, R. C. Gupta and H. S. Ray: Scand. J. of Metall., 30 (2001), 14.

20) E. Kawasaki, J. Sanscrainte and T. J. Walsh: AIChE J., 8 (1962), 48.

21) C. Cicutti, M. Valdez, T. Perez, R. Donayo and J. Petroni: Latin Am. App. Res., 32 (2002).

22) C. Cicutti, M. Valdez, T. Perez, J. Petroni, A. Gomez, R. Donayo and L. Ferro: 6th Int. Conf. on Molten Slags, Fluxes and Salts, Stockholm-Helsinki, (2000), 367

23) K. H. Sandhage and G. J. Yurek: J. Am. Ceram. Soc., 71 (1988), 478.

24) E. T. Turkdogan: Physicochemical Properties of Molten Slags and Glasses, The Metals Society, London, (1983), 183.

25) F. Oeters: Metallurgy of Steelmaking, Verlag Stahleisen, Dusseldorf, (1994), 219.

26) G. Tromel and E. Gorl: Stahl Eisen, 83 (1963).

27) M. Kowalski, P. J. Spencer and D. Neuschutz: Phase Diagrams, Verlag Stahleisen GmbH, Dusseldorf, (1995), 126, 170.

$28)$ Y. Chen, G. A. Brooks and S. A. Nightingale: Can. Metall. Q., 44 (2005), 323.

29) W. E. Ranz and W. R. Marshall: Chem. Eng. Prog., 48 (1952).

30) R. Clift, J. R. Grace and M. E. Weber: Bubbles, Drops and Particles, Academic Press, New York, (1978).

31) B. J. Keene and K. C. Mills: Density of Molten Slags, Verlag Stahleisen GmbH, Dusseldorf, (1995), 313.

32) K. C. Mills: Viscosities of Molten Slags, Verlag Stahleisen GmbH, Dusseldorf, (1995), 353.

33) Y. Sano, N. Yamaguchi and T. Adachi: J. Chem. Eng. Jpn., 7 (1974), 255.

34) G. A. Brooks and Subagyo: Yazawa Int. Symp. Metall. Mater. Proc., Prin. Tech., San Diego, CA, USA, (2003), 965.

35) Y. Zhang and R. J. Fruehan: Metall. Mater. Trans. B, 26B (1995), 813.

36) R. Jiang and R. J. Fruehan: Metall. Mater. Trans. B, 22B (1991), 481

37) J. J. Bikerman: Trans. Faraday Soc., 34 (1938), 634.

38) K. Ito and R. J. Fruehan: Metall. Mater. Trans. B, 20B (1989), 509.

39) P. Misra, B. Deo and R. P. Chhabra: ISIJ Int., 38 (1998), 1225.

40) A. Masui, K. Yamada and K. Takahashi: McMaster Symp., McMaster University, (1976), 1.

41) S. Asai and I. Muchi: Trans. Iron Steel Inst. Jpn., 10 (1970), 250.

\section{Appendix}

\section{A. Estimation of Temperature Profile of Metal and Slag Phases}

It is known that the temperature of metal bath $\left(T_{\mathrm{b}}\right)$ increases linearly during the oxygen blow with regard to the previous studies. $^{40,41)}$ Accordingly, the temperature of slag is assumed $100^{\circ} \mathrm{C}$ more than the temperature of metal. The metal temperature can be approximated using;

$$
T_{\mathrm{b}}=z \cdot t+T_{\mathrm{b}, 0}
$$

where $z$ is a constant varying from one practice to another. The temperature of molten metal was determined by modifying Eq. (A.1) for the study by Cicutti et al. using the measured initial and final temperatures;

$$
T_{\mathrm{b}}=17.65 \cdot t+1350
$$

\section{B. Estimation of Physical Properties of Slag}

Part 1. Model for Estimating the Density of Multicomponent Slag

Model for density of slag has been widely used, which is given in Eq. (A.3). The recommended values for the molar volume of slag constituents are given in Table B1. ${ }^{31)}$

$$
\begin{aligned}
& \rho_{\mathrm{s}}=\frac{M_{\mathrm{SiO}_{2}} x_{\mathrm{SiO}_{2}}+M_{\mathrm{CaO}} x_{\mathrm{CaO}}+M_{\mathrm{MgO}} x_{\mathrm{MgO}}+M_{\mathrm{MnO}} x_{\mathrm{MnO}}+M_{\mathrm{FeO}} x_{\mathrm{FeO}}}{V_{\mathrm{s}}} \\
& V_{\mathrm{s}}=x_{\mathrm{SiO}_{2}} V_{\mathrm{SiO}_{2}}+x_{\mathrm{CaO}} V_{\mathrm{CaO}}+x_{\mathrm{MgO}} V_{\mathrm{MgO}}+x_{\mathrm{MnO}} V_{\mathrm{MnO}}+c_{\mathrm{FeO}} V_{\mathrm{FeO}}
\end{aligned}
$$

where $M$ is molar weight $(\mathrm{g} / \mathrm{mol}), X$ is mole fraction and $V_{\mathrm{s}}$ is partial molar volume of the slag constituents.

Part 2. Model for Estimating the Viscosity of Multicomponent Slag

It has been known that viscosity of melt is sensitive to its ionic or molecular structure so the changes in composition of slag and temperature profile of the slag should be included. The model of Urbain et al. ${ }^{32)}$ is considered in this calculation. Based on this model, slag constituents are divided into three groups for metallurgical slags:

1. Glass formers, $x_{\mathrm{G}}=x_{\mathrm{SiO}_{2}}+x_{\mathrm{P}_{2} \mathrm{O}_{5}}$

2. Modifiers,

$$
\begin{aligned}
x_{\mathrm{M}}= & x_{\mathrm{CaO}}+x_{\mathrm{MgO}}+x_{\mathrm{MnO}}+x_{\mathrm{FeO}}+1.5 x_{\mathrm{Fe}_{2} \mathrm{O}_{3}}+x_{\mathrm{Na}_{2} \mathrm{O}}+x_{\mathrm{K}_{2} \mathrm{O}} \\
& +3 x_{\mathrm{CaF}_{2}}+2 x_{\mathrm{TiO}_{2}}+2 x_{\mathrm{ZrO}_{2}}
\end{aligned}
$$

3. Amphoterics, $x_{\mathrm{A}}=x_{\mathrm{Al}_{2} \mathrm{O}}+x_{\mathrm{B}_{2} \mathrm{O}_{3}}$

Normalized values $x_{\mathrm{G}}^{*}, x_{\mathrm{M}}^{*}$ and $x_{\mathrm{A}}^{*}$ are obtained by dividing the mole fractions, $x_{\mathrm{G}}, x_{\mathrm{M}}$ and $x_{\mathrm{A}}$ by the term $\left(1+0.5 x_{\mathrm{FeO}_{1.5}}+x_{\mathrm{CaF}_{2}}+x_{\mathrm{TiO}_{2}}+x_{\mathrm{ZrO}_{2}}\right)$. Parameter $B$ can be found using

$$
B=B_{0}+B_{1} x_{\mathrm{G}}^{*}+B_{2}\left(x_{\mathrm{G}}^{*}\right)^{2}+B_{3}\left(x_{\mathrm{G}}^{*}\right)^{3}
$$

$\alpha$ is $x_{\mathrm{M}}^{*} /\left(x_{\mathrm{M}}^{*}+x_{\mathrm{A}}^{*}\right)$ and $B$ values can be found from Table B2. Parameter $A$ can be found by Eq. (A.6) and viscosity of slag (in poise) can then be determined by using Eq. (A.7).

$$
\begin{aligned}
-\ln A & =0.2693 B+11.6725 . \\
\mu_{\mathrm{s}} & =A T \exp \left(10^{3} B / T\right) \ldots \ldots \ldots
\end{aligned}
$$

Table B1. Recommended values for partial molar volume of slag constituents at $1500^{\circ} \mathrm{C}{ }^{31)}$

\begin{tabular}{|c|c|}
\hline Constituent & $\mathrm{V}\left(\mathrm{cm}^{3} / \mathrm{mol}\right)$ \\
\hline $\mathrm{CaO}$ & 20.7 \\
\hline $\mathrm{MgO}$ & 16.1 \\
\hline $\mathrm{MnO}$ & 15.6 \\
\hline $\mathrm{FeO}$ & 15.8 \\
\hline $\mathrm{SiO}_{2}$ & $19.55+7.996 x_{\mathrm{SiO}_{2}}$ \\
\hline
\end{tabular}

Table B2. B parameters for calculating the viscosity of slag. ${ }^{32)}$

\begin{tabular}{|c|}
\hline$B_{i}=\alpha_{i}+b_{i} \alpha+c_{i} \alpha^{2}$ \\
\hline$B_{0}=13.8+39.9355 \alpha-44.049 \alpha^{2}$ \\
\hline$B_{I}=30.481-117.1505 \alpha+139.9978 \alpha^{2}$ \\
\hline$B_{2}=-40.9429+234.0486 \alpha-300.04 \alpha^{2}$ \\
\hline$B_{3}=60.7619-153.9276 \alpha+211.1616 \alpha^{2}$ \\
\hline
\end{tabular}

